\title{
Agricultural Land Protection by Spatial Planning in Bulgaria ${ }^{3}$
}

\begin{abstract}
Agricultural land is a basic resource for the livelihood of the Bulgarian population. However, its management is unstable and is connected with many unresolved or wrongly resolved problems which make it difficult to exercise its underlying function. This is mainly due to fragmented land legislation that has a number of disadvantages: the transformation of agricultural land into urban land is easy, control of land quality is poor, and there is a deficiency of agricultural spatial planning regulations. One of the specific tools for preserving the natural function of agricultural land is spatial planning, subject to the strategic documents of the country. According to a newly elaborated concept on agricultural territory planning, this process is two-staged: on the municipal and on-farm level. The objectives of the paper are: 1) to analyze the effectiveness of national legislation in regard to preserving the natural function of agricultural land; 2) to defend the necessity of the normative framework completion with precise spatial planning rules for agricultural land, and finally; 3 ) to draw attention to a new concept on agricultural territory planning by presenting the basic cadastral and specific data for performing spatial GIS analyses and elaborating spatial plans. Data from national statistical institutions were used, and methods of analysis and synthesis were applied. The data needed for GIS analyses and elaboration spatial plans for agricultural territory are listed. The paper asserts that spatial planning is a tool for regulating agricultural land use, for setting territory conditions for preserving and improving land quality, for protecting land tenure rights and for developing successful and high-income agribusiness.
\end{abstract}

Keywords: agricultural land, legal framework, spatial planning, concept, GIS data

Received: 13 April 2020; accepted: 15 May 2020

(C) 2020 Authors. This is an open access publication, which can be used, distributed and reproduced in any medium according to the Creative Commons CC-BY 4.0 License.

1 University of Architecture, Civil Engineering and Geodesy, Faculty of Geodesy, Sustainable Land Use and Real Estate Management, Sofia, Bulgaria, email: bismarinova@gmail.com

2 University of Architecture, Civil Engineering and Geodesy, Faculty of Geodesy, Sustainable Land Use and Real Estate Management, Sofia, Bulgaria, email: mdmoteva@gmail.com

ORCID ID: https://orcid.org/0000-0002-9861-2966

3 UACEG Center for Research and Design (Project BN 209/18 Guidelines for Agricultural Land Design) 


\section{Introduction}

The preservation of the permanent purpose of use of agricultural land is the subject of an international tool like [1]. There are a number of documents within the European Union that address agricultural land and demonstrate the importance of its governance [2-6]. In spite of efforts taken to protect its essential function, agricultural land is converted into artificial under the pressures of urbanization and infrastructure [7, 8]. Every year, almost 1,000 $\mathrm{km}^{2}$ of EU agricultural and natural area disappears and there is no apparent slowing of this trend [9].

In order to cope with the situation, two strategies are foreseen which implementation deadline is 2020:

- improving land-use planning with the avoidance of building up fertile land by $10 \%$, i.e. improving the local management of each square meter by revealing its production capacity and keeping the national production within limits of a safe operating space (controlling the number of square meters used);

- investing in the regeneration of degraded soils (restore 1/3 of degraded and abandoned lands) [7].

Agricultural land is a basic resource for the livelihood of the Bulgarian population. Proper protection of high capability land is a matter of great importance [10]. Given the limited land resources and the need to create conditions for sustainable development, a number of strategic documents have been adopted [11-14]. The most important and the first in the hierarchy in the normative framework is the Constitution of R. Bulgaria [15], followed by the group of acts that generally affect landed property [16-22], regional and spatial development [23, 24], land quality preservation [25-28], and land relations [29-32]. There is a set of Ordinances that regulate particular activities, such as land use, land planning, land registration, territory development, easements, land valuation, land reclamation, etc. [33-36]. The listed land legislation contains deficiencies, which cause land-use conflicts and public interest disturbance. They follow down the whole chain: governance - administration - physical level management. The main fields affected are agricultural production function and land quality.

One of the specific tools for preserving the natural function of agricultural land is spatial planning but its influence on land protection nowadays is limited. Agricultural areas are only identified in the GDPs without rules for their development and shaping [10].

Following the country's accession to the EU in 2007, the laws concerning spatial planning were greatly improved in the direction of sustainable land development but agricultural land planning does not fall into the focus of their attention. This is a basic reason for the already well-revealed and analyzed a great number of problems, connected with land operation: no legal control of on-farm structures; no regulations on the permissible areas for landed property and land lease; weakly 
defended tenure rights; no requirements on land buyers; no legal control on the land market and land cycle; no strict control of the change of the agricultural purpose of use; very loose control on land protection; no regulations on agricultural land-use and physical planning. In general, land legislation is fragmented, which is a precondition for existing legal inconsistencies. All this poses risks of loss of arable land. Attendant consequences are the irrational use of agricultural machinery, suboptimal organization of work; destruction of the agricultural infrastructure. Bad territorial conditions in general affect the economic development of farms, regions, and the state. Resolving the land-use conflicts is about reducing, mitigating and offsetting the negative effects of land management so far.

The objectives of the paper are 1) to analyze the effectiveness of the national legislation in regard to some issues on preserving the natural function of agricultural land, 2) to defend the necessity of the completion of a national legislation framework with spatial planning rules for agricultural land, and 3) to draw attention to a new concept in agricultural territory planning by presenting the basic cadastral and specific data to perform spatial GIS analyses and spatial plans.

\section{Material and Methods}

While developing the ideas of the study, the following scientific methods and approaches were used:

- documentary analysis - collection, processing, and analysis of normative, strategic, historical and other documents from the country and abroad on rural development, including state ordinances, municipal acts, analytical reports, land-use plans and maps, censuses;

- quantitative and qualitative methods for collecting and processing information, based on economic, geographic and statistical data from strategies, plans, programs and projects developed, analyzes, forecasts and anticipated planned development of the agricultural territories; farm and economy data from agrarian reports, statistical reports, and official registers; publications and documents of state bodies and departments;

- expert assessment for outlining of the content, scope and necessary data for agricultural spatial plans preparation in the GIS environment.

We obtained results from a critical analysis of some aspects of the agricultural legal regime on the definition of agricultural land, the size of landed property and land consolidation, the property rights and the control on the preservation of land quality, and the change of the permanent purpose of use. The legal regime on the agricultural territorial development was discussed and some shortcomings were outlined. The previously developed concept on agricultural land planning was briefly presented and basic data for GIS analyses and elaboration of spatial plans highlighted. 


\section{Results and Discussion}

\subsection{Critical Analysis of Some Aspects of Agricultural Land Legal Regime}

\section{Definition of Agricultural Land}

The Constitution [15] states in Art. 21, paragraph 2 that arable land is used only for agricultural purposes. The uncertainty of agricultural land management begins with the definition of agricultural land in Art. 2 of [21], which doesn't provide a clear explanation of the function of agricultural land while defines it by refuting claims. This definition is scattered into several acts. The land which is intended for agricultural production is that which is not: 1) located in the urban territory; 2) included in the forestry fund; 3) built-up with industrial or other enterprises' buildings; 4) occupied by mines and quarries, and of any energy, irrigation, transportation or other facilities. Art. 1, paragraphs 2 and 3 of [27] add to the agricultural land the farmyard of former Labor-Cooperative Agricultural Entities outside an urban territory if not built-up and also a built-up under certain conditions land. Art. 2, paragraph 2 of [25] specifies that agricultural land is used only for agricultural production, which means crop production and grazing of livestock in a manner that does not impair soil health and fertility. What is important for these definitions is that the law's criterion when defining the permanent purpose of use (agricultural) is the nature of the agricultural land, not the way it is used.

According to the permanent purpose of use, Art. 7 of [24] determines seven territory types among which is the agricultural territory. The boundaries of these territories are determined by a General Development Plan (GDP) (Art. 7 of [24]). The agricultural territory is put in second place after the urban in the type list, which reveals its significance in the national space and economy.

The specific purpose of use of the landed property is defined by Art. 8 of [24]. It is regulated that the specific purpose of use is to be determined by a Detailed Development Plan (DDP). However, the legal framework for 'agricultural territory' in it is scarce. The specific purpose of the use of landed property in the agricultural territory can be (Art. 8, item 2 of [24]): for arable land (cropping fields, orchards and vegetable gardens; vineyards; meadows; etc.) and for non-arable land (pastures, sloped lands, gullies, ravines, etc.). Also, agricultural land can have the provisioning status of permitted change of the agricultural purpose of use or of prohibited change of the agricultural purpose of use [33]. A contextual and terminological discrepancy between Art. 14 of [34] and Art. 8 of [24] exists. It is said in Appendix 2 at Art. 14 of [34] (Appendix 2 presents the Classifier for the Methods of Permanent Purpose of Use of the Landed Properties with Corresponding Codes) that the landed properties in the agricultural territory can have one of four methods of permanent use: arable land, permanent crops, permanent pastures, and permanent meadows. They have corresponding cadastral codes. This classification reflects FAO definitions for agricultural land and indicators [37]. 
The lack of a single land law is a precondition for a legal weakness still in the definitions of agricultural land and this presupposes subsequent disadvantages of the legal framework on land.

\section{Size of a Landed Property}

Bulgaria needs sound legislation against further fragmentation by market sales, inheritances and other forms of land relationships [10].

The minimum sizes of the landed properties, according to the provisions of Art. 72 of [19] and Art. 7 of [21] are important for the preservation of the permanent purpose of use of agricultural land. According to these acts, divisions, expropriations, change of the permanent or specific purpose of use, disposal of real parts of agricultural property is carried out if the individual parts can be separated into individual properties with the following minimum sizes: $>0.3$ ha for arable land, $>0.2$ ha for meadows, and $>0.1$ ha for vineyards and orchards. This is a precondition for maintaining the fragmentation of the landed properties in Bulgaria. In order to prevent further fragmentation, it is necessary to increase the minimum size of the agricultural properties set out in [19].

Under [21], the agrarian reform restored the landed property rights to the maximum 20 ha for the country and the maximum 30 ha for the Dobrich region (the most fertile chernozems region). These limitations had been determined by the old and later repealed Labor Land Property Act [38]. Claims for agricultural land over these sizes were indemnified by money.

The current normative framework does not place any obstacles to further division of the properties by inheritances, divisions, and sales, nor to regulating the land cycle by putting requirements on land buyers, like for example in Germany [39].

Legislation has been self-contradictory in relation to land ownership. [21] have been amended and supplemented almost 67 times during that process in a way of self-rejecting or asserting. For example, Art. 23 of [22] stipulates that land consolidation shall be observed when restoring the rights on land ownership. A supplementary text to the provision of Art. 23 (SG 48 of 1995) stated that the properties that fall into the areas of members of cooperatives, commercial companies or groups of owners, can be grouped in separate areas and quarters at the request of the owners. It is indicated that they should not be fragmented if possible. The next amendment is in 1997 (SG 122 of 1997), in which it already completely deviates from the land consolidation principles was that the properties to be restored in a fragmented manner according to the distribution of 1945-1958. Unfortunately, the consequences of this are the long-term impact on land relations, which affect agricultural production itself.

Another insufficiency of the law is that it does not set the deadline and conditions for the completion of administrative restitution, which is an obstacle to the proper use of the land for its intended purpose. The restoration of the ownership of agricultural land in existing or recoverable old real borders, as well as on properties included in urbanized territories, is continuing. 


\section{Land Consolidation}

Nowadays, in line with the market logic and as a result of the implementation of the CAP, land consolidation is done in two evident ways: 1) acquisition of property and 2) under contracts for use of agricultural land. The consolidation of land ownership is regulated in Art. 37e of [21] (am. SG 13 of 2007). The terms and procedures for creating and approving land consolidation plans are regulated in [22] with the creation of a new Chapter Nine "Land consolidation on an agreement of the owners" (SG 45 of 2008). The pilot projects that had been implemented in a total of six villages in the country were partially successful - where sufficient state land was available, and where the consolidation process was at the expense of the state. These were the signals that the voluntary principle regulated by the law is doomed to failure. Nevertheless, the rules today provide for entirely voluntary land consolidation. What is more, the agricultural lands from the municipal and state land fund have not been involved to date. The nine land consolidation plans in the country were initiated by large owners of agricultural land, mainly legal entities. On the other hand, there is no interest in the part of the large landowners in implementing consolidating their property. Due to the nature of the landed property in the country (small, fragmented ownership, co-ownership), land consolidation projects if any will cover relatively small territories with a limited number of participants. In order to overcome the identified problems were introduced amendments of [21] (SG 14 of 2015). The registration procedure was facilitated. There are no fees for entering the changes in the Landed Property Distribution Map or in the cadastral map, also for issuing sketches for land consolidated properties. The Ministry of Agriculture, Food and Forestry assists the process by providing methodological assistance and free data and materials for the land concerned, including those for which a cadastral map and cadastral register have been approved. A positive step is that the land consolidation plan may modify the agricultural roads where access to the landed properties of off-plan owners is not required or be designed according to the needs of the plan.

Legislation still has several tasks ahead of it in opening up the road to land consolidation. It has to oblige the state to interfere with land consolidation by financial and administrative mechanisms. Also, it has to facilitate the process of achieving the co-owners consent to join the land consolidation project. The state should not let land consolidation arise as a result of land market transactions: it has to be a scientifically based process, controlled by the state.

\section{Property Rights and the Control on the Preservation of Land Quality}

Land ownership is inviolable, in accordance with Art. 17, paragraphs 1 and 3 of [15]. This Article grants an absolute and unlimited right to land ownership. At the same time, Art. 21, paragraph 1 of [15] explicitly emphasizes that: "Land is the main national wealth that enjoys the special protection of the state and society". 
Unlike Art. 17 of [15], Art. 21 of [15] doesn't guarantee rights. It is only declarative with respect to the perception of land by the state and society. It doesn't guarantee the public interest in land protection. This predisposes subsequent legislation to be hesitant about the problem of protection of agricultural land in the interest of the investors. Art. 17 of [15] and Art. 15 of [30] create a serious obstacle to proper land use and protection.

According to Art. 5, paragraph 1 of [25] the owner is free to choose the method of the agricultural use, if this does not change its purpose and does not harm the land of the other owners or the quality of surface and groundwater.

Art. 6 [25] lists the forbidden activities for agricultural land. The non-enforcement of these prohibitions by the owners or users is bound by the respective sanction (Art. 41, paragraph 1 of [25]) for, for example, the use of agricultural land for non-agricultural purposes without permission being granted to change its purpose, construction of an object over a larger than permitted area. But according to the authors' opinion, the punitive measures are too small to have a direct effect on the behavior of owners towards the land. There is no mechanism, and [25] does not envisage a hypothesis for seizing the powers of the administrative penal authority in case it fails to fulfill its obligations under the law. Art. 42, paragraph 1, item 1 of [25] provides for punishment of an official who issued an order for approval of a DDP without a decision on an approved site by the competent commission. According to the provisions of [24], the approval of a DDP is also carried out by a decision of the municipal council.

The country has set up a common strategic framework regulating the protection of the environment and its elements, proposing a package of actions to ensure the achievement of its objectives. Essentially, the national strategies and documents developed represent a step towards the sustainable development of land resources but lack both adequate institutional coordination and clearly defined financial resources for the realization of the goals they set. It is necessary to minimize the appealing nature in most of the laws, through incentives and sanctions in execution and, respectively, violation. Most of the land-related laws stipulate that it should be managed with the care of a good farmer, but if this requirement is not met, no consequences arise.

\section{Change of the Permanent Purpose of Use}

The change of the permanent purpose of use of agricultural land for non-agricultural purposes is allowed depending on the productive qualities of the land and the purpose of the change (Art. 17, paragraph 1 of [25]). Agricultural Land Protection Act [25] has introduced very liberal procedures, which sets conditions for investment pressure on agricultural land. Moreover, the lack of full protection of agricultural land results in speculative land purchases, and consequently, this makes agricultural land unavailable for individuals engaged in agricultural production [10]. 
Outside the boundaries of urban territory, construction is allowed subject to Art. 59, paragraph 1 of [24]: 1) following the projections of an effective GDP; 2) on the basis of an existing DDP or a parcel plan (PP) for the elements of the technical infrastructure. If construction in agricultural land is allowed, this area has to be outlined in a GDP; 3) after changing the purpose of the land when required by a special law. The change of the agricultural purpose of use shall be made by a DDP (Art. 7-9 of [24]). Directly associated with this problem are three legal documents: [25], [26] and [36]. The change of the agricultural purpose of use for non-agricultural needs is allowed for (Art. 17a of [25]): 1) construction of technical infrastructure within the meaning provided by the [24]; 2) extension of the built-up boundaries of an urban territory; 3) creation or extension of separate individual regulated land property borders out of the built-up borders of an urban territory.

The law is explicit in the protection of the highly fertile land by separating three cases of land quality when allowing construction. Building-up an area: 1) of $>50$ ha of $1^{\text {st }}$ to the $4^{\text {th }}$ land category and irrigated is allowed by the Council of Ministers on a case-by-case basis (Art. 23, paragraph 1 of [25]); 2) of $<5$ ha of $5^{\text {th }}$ to the $10^{\text {th }}$ category, not irrigated, or in settlements is allowed by a Commission to the local Regional Directorate of Agriculture (Art. 17, paragraph 1, item 1 of [25]); 3) in all other cases -by the Commission for Agricultural Land at the Ministry of Agriculture, Food and Forestry (Art. 17, paragraph 1, item 2 of [25]). There are criteria for changing the permanent purpose of use for building up photovoltaic parks to be placed on non-irrigated agricultural land of categories $7^{\text {th }}$ to the $10^{\text {th }}$ or non-categorized land. But traveling across the country, one can see large areas of fertile land occupied by such renewable energy sources. This is because the limitations are not valid in case the electricity is produced by the landowners for their own needs (Art. 23, paragraph 3 of [25]).

With the adopted normative changes in October 2018, a more favorable regime for the investors has been created, due to:

- Withdrawal of the requirement a DDP to be submitted at the request for approval of an area for construction. Only a cadastral sketch of the landed property is required or a draft sketch with specified boundaries and area determined by geodetic coordinates when the plot is part of landed property. (Art. 21, para 1 of [25]).

- Relieved procedures for incorporating land into the urban borders (settlements and settlement formations). In the land, which has in changed its agricultural purpose of use in recent years, it will be possible to carry out construction, but only if the landowner demands permission for this construction from the relevant commission. The maximum term was 6 years and it was canceled in 2017. Now, the time for the realization of an investment in a land, which has mixed specific uses (e.g. agricultural together with recreation one), will prolong endlessly. Anyway, the agricultural land has lost its permanent purpose of use. 
- Change of the purpose of the agricultural land for non-agricultural needs, envisaged by a GDP in force and in the case of the execution of a concession contract shall be processed without carrying out a procedure for the approval of a plot or a track route (Art 17a, paragraph 3 of [25]).

- It is the mayor's proposal for the change of the agricultural purpose of use in the borders of urban territory in accordance with the GDP (Art. 20, paragraph 2 of [25]).

- Two new paragraphs 30 and 31 have been added to the Bill on Amending and Supplementing the Seed and Seedlings Act (adopted SG on January 24, 2018), according which the investor will no longer pay new fees for changing the status of the land, only if there is an increase due to additional environmental standards.

A trial for the protection of agricultural land from being built up is Art. 134, paragraph 3 of [24] according to which the existing GDP should be amended before the modification of DDP. The DDP modification should be approved after the approval of GDP amendments. Experience testifies to the formal change of GDP (because of serving the investor's interest).

Agricultural land under pastures and meadows has higher levels of protection. The common such areas are under the public municipal property. When a change of the permanent purpose of use is required, the Municipal Council adopts a decision by a majority of two-thirds of the total number of municipal councilors. Changing the agricultural purpose of use is permitted when it is envisaged by acting GDP, for building objects of national importance or municipal objects of primary importance ( $\S 6 \mathrm{a}$ of the Transitional and Final Provisions of [25]). The control of the change of the permanent purpose of use when it services the private interest is carried out, first, by the Municipal Council - it has to give its agreement, second, by the Minister of Agriculture, Food and Forestry - he has to agree when the required area is included in the "Permanent Grassland" layer of the Land Parcel Identification System.

There are no provisions by GDP permitting the building up of agricultural areas without changing its permanent purpose of use. But the Legislator has also envisaged a procedure whereby the existence of certain conditions makes it possible to build on agricultural land (within the meaning of [21, 25, 26]) for the cases without changing the permanent purpose of use. The actual building does not make the agricultural area non-agricultural [36]. This can be applied to greenhouses and all other buildings that serve agricultural production. The ability of a natural and/or legal person to build under [36] has not been set depending on the category of land, the method of the permanent purpose of use and irrigation. What is more, it gives the right to build a two-stage house if the landed property has an area $>1$ ha and a DDP is required (Art. 2, paragraph 2 of [36]). Although the restrictions for construction are well specified in Art. 3 of [36], this creates a condition for speculation. 


\subsection{Critical Analysis of the Legal Regime on the Agricultural Territorial Development}

With the development of democratic processes and agrarian reform in Bulgaria, publications have appeared expressing opinions on the new principles of land development and the conceptual renewal of spatial planning theory, in line with the new needs of society [40-48]. They justify the necessity to carry out territorial development activities as a basis for the sectoral activities in agricultural territory.

The attention of the scientific community is focused mainly on land consolidation as a first step towards the rationalization of land use. The national conditions for consolidation are considered to be favorable but there are barriers that are difficult to overcome, mainly financial and psychological. Land Consolidation Bills have been written and their aim was to make agricultural activity a normal and profitable one, and agricultural land a permanent source of a high and stable income. None of them was promoted since they were assessed as insufficiently complex.

The need for long-term planning in agricultural areas was grounded in relation to integrated and holistic land use. Agricultural land use should rely on the natural characteristics and land resources, the ecological problems, the specialization and concentration of agricultural production over the country, the local production traditions, the technological level and availability $[49,50]$.

Agricultural territory planning is affected in the present legal framework by $[19,21,25,29]$ and other regulatory and sub-normative documents. Art. 111 of [24] regulates a Specialized Detailed Development Plan (SDDA) which solves particular spatial problems in the territory of the municipality in agricultural, forestry, disturbed and protected areas. [21] addresses some issues of one-year planning in land use (Art. 37B), and land consolidation (Art. 37e). [25] foresees measures for the conservation of soil fertility and for its restoration in areas with proven necessity.

None of the laws governing agricultural land reflects a comprehensive management concept based on integrated planning, namely one consisting of objectives, measures, and actions, based on technological indicators. There is no regulated terminology associated with such planning, although some sub-normative and legal-administrative acts use some. The terms "land-use project" and "land-use plan" are found in the planning and strategic documents for the development of the municipalities in their agricultural units. They are also mentioned in some legal and administrative acts that solve private property problems. As a consequence of the ambiguity and gaps in the legal framework, the activity of planning the agricultural territory exists in a chaotic and non-holistic form. In practice, no scientifically grounded plans for the development of the agricultural territory are currently being developed, both at the level of administrative-territorial and territorial units, as well as on-farm level. Also, there are no mandatory requirements for planning the activities in the agricultural territory under any of the land laws, according to the potential of the land and its ecological needs. 


\subsection{The Concept on Agricultural Land Planning and the Basic Data to Perform GIS Analyses and the Elaboration of Spatial Plans}

An outline of a modern Agricultural Territory Development Concept (ATDC) has been developed in $[49,50]$. ATDC proposed approaches for long-term strategic land planning on the municipal level and short-term land planning on the farm level. ATDC offers the completion of SDP with details for the Agricultural Territory; includes recommendatory development zones that are based on the natural recourses distribution, quality of land and zoning of agricultural production in the country; outlines regimes and optionality of the territorial elements and development zones. The aim is to preserve the farmland for its main function.

The recommended main development zones in an agricultural territory can be:

- Market-oriented agricultural production development zone: a major part of the agricultural territory with a long-term regime. It will cover the main methods of permanent use: crop rotation area, permanent crops, pastures and meadows.

- Suburban agricultural zone for cities-centers (of $1^{\text {st }}$ and $2^{\text {nd }}$ hierarchical levels according to [12]) and for settlements with forecasts for increasing their economic and social activity. The indicators of this development zone are similar to those of the market-oriented agricultural production development zone, but with adapted values given its specific features [51].

- Urban farming zone within urban areas, mainly in cities-centers [12]. The planning tool is the DDP by the order of Art. 15-17 of [24].

In order to fulfill the commitment of Art. 106, items 1 and 2 of [24] that GDP is set up for all types of territories, including the agricultural ones, it is necessary to develop a concept-scheme for agricultural spatial development in the scope of GDP of a recommendatory nature. Its implementation will be stimulated by subsidizing and land tax policies and other financial mechanisms. Art. 2 of [33] to be amended by recommendatory sub-zones and territories with recommendatory regimes for crop growing, applying different systems of agriculture, ameliorations, measures for the prevention of degradation processes, etc., corresponding to the local soil and climatic conditions and as an extensive approach to maximize the land use.

A large amount of information has to be processed and GIS are appropriate to delineate the appropriate zones according to required criteria. The main stream of information will be digital data and detailed textual data on:

- GDP for territories and zones, including nature zones with regimes;

- digital schemes of special land funds;

- topographic-geodetic map and data;

- soil map and data with land categorization;

- agrochemical and geo-botanical composition of the soil; 
- agro-climatic zoning;

- zoning of agricultural production;

- zones with environmental issues;

- draft projects on preserving and enhancing soil fertility, i.e. on: land reclamation; erosion control; prevention from floods, swamping, drought, secondary soil compaction, and salinization; restoration and conservation of industrially contaminated lands;

- areas with restrictions on land-use;

- disputed areas in terms of agricultural or forest territory;

- inventory of land use in the agricultural territory, including unused and irrationally used agricultural land and used for non-agricultural purposes;

- special thematic maps on the status and use of land in the agricultural territory;

- other types of land information according to the tasks and objectives of the land management.

The Concept provides general characteristics of a Land Use Plan (LUP) (instead of SDDP) and its territorial elements at the farm level as a matter of private initiative without stringent requirements and rules. LUP regulation could be to [38] in a separate chapter entitled "Specialized Detailed Development Plan (or Land-Use Plan) for the Agricultural Territory".

The following general types of data have to be collected and processed:

- landed property cadastral data - unique ID number in the Uniform Classifier of Administrative-Territorial and Territorial Units (EKATTE), geodetic coordinates of the turns of the property borders, area, locality, owner's name, neighbors' names;

- landed property nature characteristics - soil taxonomic unit code, soil taxonomic unit name, code for soil mechanical composition, land capability for growing crops, topographic information: existing elements of the territory, slope of the terrain, exposure of the terrain, climatic data of the settlement;

- data for ownership documents - name, ID number, property rights, easements, rent and lease, claims administrative restrictions on use;

- data on land use - method of permanent purpose of use;

- materials on land use formation, boundary tracing, preparation of land tenure and land use plan.

\section{Conclusions}

There exists a great need to revise and reconstruct the legislation on agricultural land relations and use. The regulations are fragmented and inadequate, which is why the elaboration of common unified law on agricultural land is justified. The lack of single land law is a precondition for legal weakness. The need to protect the 
public interest to extract the necessary ecosystem services from agricultural land and preserve the natural quality of the land resources points to the idea of protecting this resource and its production function through a flexible approach first applied in the legislation. The specific restrictions on the destruction of arable land, especially those of the higher category and irrigated land, as set out in the current legal regime and planning documents are insufficient. The possibility to change the permanent purpose of use of agricultural land is allowed under a rather loose legal regime that does not always meet the condition of a proven need and undermines the public interest in sustainable development.

The settlement of the land relations awaits a comprehensive normative framework on the ownership, use, conservation and management of agricultural land in Bulgaria has a bill of normative regulation forthcoming that will hopefully be adequate to the socio-economic relations in the country. It is vitally needed because the land represents a foundation for the sustainable development of agriculture as a strategic sector in the country that is important for the economic stability, national security and sustainable progress of the Republic of Bulgaria. The idea of integrated spatial planning, including agricultural land with all its characteristics and functions, should be accorded a special place in the new normative framework. The agricultural land-management plan, as an important tool for pursuing an adequate agricultural policy, should find its place in the legal framework - both as regulations and as a mandatory element of the system of planning tools and documents. The data that are needed for GIS analyses and for elaboration of spatial plans for agricultural territory is listed.

\section{References}

[1] United Nations Sustainable Development Goals. Adopted in September 2015. https://www.undp.org/content/undp/en/home/sustainable-development-goals.html [access: 13.04.2020].

[2] Directive 2001/42/EU on the Assessment of the Effects of Plans and Programmes on the Environment. https://eur-lex.europa.eu/legal-content/EN/ ALL/?uri=CELEX\%3A32001L0042 [access: 13.04.2020].

[3] Regulation 1260/99/EU on Structural Funds. https://eur-lex.europa.eu/ legal-content/EN/TXT/?uri=CELEX\%3A31999R1260 [access: 13.04.2020].

[4] Council Regulation 1268/99/EU on Agriculture and Rural Development. https://eur-lex.europa.eu/legal-content/EN/TXT/?uri=legissum:160023 [access: 13.04.2020].

[5] Regions 2020. An Assessment of the Future Challenges for EU Regions. Commission Staff Working Document. Commission of the European Communities. Brussels, 2008. https://ec.europa.eu/regional_policy/sources/docoffic/ working/regions2020/pdf/regions2020_en.pdf [access: 13.04.2020]. 
[6] Common Agricultural Policy of the European Union. https://ec.europa.eu/ info/food-farming-fisheries/key-policies/common-agricultural-policy_en [access: 13.04.2020].

[7] Bringezu S.: A finite world and increasing land demands: a global perspective. Presentation at the Land as a Resource Conference, organised by the Environment Directorate-Gemneral of the EC, 19 June, Brussels, 2014. https:// ec.europa.eu/environment/land_use/conference_en.htm [access: 13.04.2020].

[8] Ludlow D.: Tackling urban sprawl: towards a compact model of cities? Presentation at the Land as a Resource Conference, organised by the Environment Directorate-Gemneral of the EC, 19 June, Brussels, 2014.

[9] European Comission. Environment. https://ec.europa.eu/environment/ land_use/index_en.htm [access: 13.04.2020].

[10] Pawlikowska E., Popek P., Bieda A., Moteva M., Stoeva A.: Analysis of the legal methods of agricultural land protection in Central Europe on the example of Poland and Bulgaria. Real Estate Management and Valuation, vol. 25(2), 2017, pp. $58-71$.

[11] National Regional Development Strategy 2012-2022. https://www.mrrb. $\mathrm{bg} / \mathrm{bg} /$ national-regional-development-strategy-of-the-republic-of-bulgaria-2012-2022/ [access: 13.04.2020].

[12] National Concept on Spatial Development for the period 2013-2025. http:// www.bgregio.eu/media/Programirane/NKPR_28012013_Last_en.pdf [access: 13.04.2020].

[13] National Development Programme: Bulgaria 2020. http://www.strategy.bg/ StrategicDocuments/View.aspx?lang=bg-BG\&Id=766 [access: 13.04.2020].

[14] National Development Program Bulgaria 2030, approved by the Council of Ministers Decision No. 33 of 20 January 2020. https://www.minfin.bg/ en/1394 [access: 13.04.2020].

[15] Constitution of R. Bulgaria, prom. SG 56 of 13 Jul 1991, last am. and suppl. SG 100 of 18 Dec 2015.

[16] Property Act, prom SG 92 of 16 Nov 1951, last am. SG 18 of 28 Feb 2020.

[17] State Property Act, prom SG 44 of 21 May 1996, last am. SG 98 of 13 Dec 2019.

[18] Municipal Property Act, prom SG 44 of 21 May 1996, last am. SG 94 of 29 Nov 2019.

[19] Inheritance Act, prom. SG 22 of 29 Jan 1949, last am. SG 47 of 23 Jun 2009.

[20] Cadaster and Property Registry Act, prom. SG 34 of 25 Apr 2000, last am. and suppl. SG 44 of 4 Jun 2019.

[21] Agricultural Land Ownership and Use Act, prom. SG No. 17 of 1 Mar 1991, last am. SG No. 61 of 2 Aug 2019.

[22] Implementing Regulations of Agricultural Land Ownership and Use Act, prom. SG 34 of 30 Apr 1991, last am. and suppl. SG, 100 of 20 Dec 2019.

[23] Regional Development Act, prom. SG 50 of 30 May 2008, last am. and suppl. SG 21 of 13 Mar 2020. 
[24] Spatial Planning Act, prom. SG 1 of 2 Jan 2001, last am. and suppl. SG 21 of 13 Mar 2020.

[25] Agricultural Land Protection Act, prom. SG 35 of 24 Apr 1996, last am. and suppl. SG 83 of 9 Oct 2018.

[26] Implementing Regulations of Agricultural Land Protection Act, prom SG 84 of 4 Oct 1996, last am. and suppl. SG 67 of 23 Aug 2019.

[27] Environment Protection Act, prom. SG 91 of 25 Sept 2002, last am. SG 21 of 13 Mar 2020.

[28] Water Act, prom. SG 67 of 27 Jul 1999, last am. SG. бр.21от 13 Mar 2020.

[29] Agricultural Lease Act, prom. SG 82 of 27 Sept 1996, last am. and suppl. SG 55 of 3 Jul 2018.

[30] Cooperatives Act, prom. SG 113 of 28 Dec 1999, last am. SG 42 of 22 May 2018.

[31] Irrigation Associations Act, prom. SG 34 of 6 Apr 2001, last am. and suppl. 1998, last am. SG 21 of 13 Mar 2020.

[32] Agricultural Property Protection Act, prom. SG 54 of 12 Jul 1974, last am. SG 58 of 18 Jul 2017.

[33] Ordinance 8 to Spatial Planning Act, prom. SG 57 of 2001, last am. SG 22 of 2014.

[34] Ordinance No. RD-02-20-5 of December 15, 2016, on the Content, Creation, and Maintenance of the Cadastral Map and Cadastral Registers, prom. SG 4 of 13 Jan 2017, last am. and suppl. SG 8 of 25 Jan 2019.

[35] Ordinance on the Categorization of Agricultural Lands with the Change of Their Permanent Purpose of Use, prom. SG 90 of 24 Oct 1996, last am. and suppl. SG 93 of 9 Nov 2018.

[36] Ordinance No. 19 of October 25, 2012 on Construction in the Agricultural Land without Changing its Permanent Purpose of Use, prom SG 85 of 6 Nov 2012.

[37] FAO. Agriculture Indicators. http://www.fao.org/ag/agn/nutrition/Indicatorsfiles/Agriculture.pdf [access: 13.04.2020].

[38] Labor Land Property Act. SG, issue 81 of 1946; revoked, SG, issue 98 of 1997.

[39] Knoblauch R.: Mustertextteil zum Flurbereinigungsplan. Arbeitsgemeinshaft Flurbereinigung ARGEFLURB, Heft 14, Landesamt für Agrarordnung NRW, Technische Zentralstelle, Düsseldorf 1987.

[40] Andonov G.: Zemeustroystvoto - osnova za po-efektivno izpolzvane i opazvane na pozemlenite resursi. [in:] Sbornik dokladi ot Yubileyna nauchna konferentsia "60 godini UASG", vol. 8 "Geodezia, transportno stroitelstvo, geotehnika,matematika i fizika", UACEG, 2002, pp. 79-86 [Андонов Г.: Земеустройството - основа за по-ефективно използване и опазване на поземлените ресурси. [в:] Сборник доклади от Юбилейна научна конференциия "60 години УАСГ", том 8 "Геодезия, транспортно строителство, геотехника, математика и физика", УАСГ, 2002, с. 79-86]. 
[41] Delieva A., Stoeva A.: Land Reform, Cadastar [sic!] and Land use in Republic of Bulgaria. [in:] 2nd Cadastral Congress, September 19-21 2003, Krakow, pp. 167-173.

[42] Delieva A.: Za zemeustroystvoto. Geodezia, kartografia i zemeustroystvo, no. 5-6, 2007, pp. 10-15 [Делиева А.: За земеустройството. Геодезия, картография и земеустройство, бр. 5-6, 2007, с. 10-15].

[43] Delieva A.: Komasatsiyata - instrument za upravlenieto na zemepolzvaneto. Geodezia, kartografia i zemeustroystvo, no. 3-4, 2009, pp. 16-21 [Делиева А.: Комасацията - инструмент за управлението на земеползването. Геодезия, картография и земеустройство, бр. 3-4, 2009, с. 16-21].

[44] Stoeva A., Delieva A.: Upravlenieto na zemedelskiteimoti v Republika Bulgaria. Geodezia, kartografia i zemeustroystvo, no. 1, 2001, pp. 18-21 [Стоева А., Делиева А.: Управлението на земеделските имоти в Република България. Геодезия, картография и земеустройство, бр. 1, 2001, с. 18-21].

[45] Stoeva A., Delieva A.: The Cadastre and Real Estate Management. [in:] 2nd Cadastral Congress, September 19-21, 2003, Krakow, pp. 53-59.

[46] Stoyanov K.: Kak shte badat izgotveni i prilozheni OUP zazemedelskite teritorii? Geodezia, kartografia i zemeustroystvo, no. 5-6, 2013, pp. 32-38 [Стоянов К.: Как ще бъдат изготвени и приложени ОУП за земеделските територии? Геодезия, картография и земеустройство, бр. 5-6, 2013, с. 32-38].

[47] Moteva M., Mondeshka M., Stoeva A., Yarlovska N.: Contemporary issues of land use and water management for agriculture in Bulgaria. [in:] Proc. Int. Sci. Congress "Life Sciences, a Challenge for the Future", 23-25 Oct., 2014, Iaşi, Romania [CD version].

[48] Moteva M. et al.: Current Issues and Challenges to Land Management in Bulgaria. Project BN 174/14, UACEG, Sofia 2015 [unpublished data].

[49] Moteva M.: Spatial Planning of the Agricultural Territory in Bulgaria - How to Fill the Gap? Micro, Macro \& Mezzo Geoinformation, vol. 10, 2018, pp. 22-35.

[50] Moteva M., Parashkevova D.: Planning tools for Agricultural Territory in Bulgaria. [in:] IOP Conference Series Earth and Environmental Science, vol. 362, 012034, 2019.

[51] Yarlovska N.: Specific Regulatory and Planning Tools for Agricultural Land Development in Suburban Areas. UACEG, Sofia 2017 [Ph.D. thesis].

\section{Planowanie przestrzenne jako narzędzie do ochrony gruntów rolnych - przykład Bułgarii}

Streszczenie: Grunty rolne są dla ludności bułgarskiej podstawowym źródłem utrzymania. Mimo to zarządzanie nimi jest nieusystematyzowane, co wiąże się z wieloma nierozwiązanymi lub źle rozwiązanymi problemami, które utrudniają 
wykorzystanie tych gruntów zgodnie z ich podstawowymi funkcjami. Wynika to głównie z rozproszonego ustawodawstwa, które ma szereg wad: przekształcanie gruntów rolnych w grunty miejskie jest łatwe, kontrola jakości gruntów jest słaba, a przepisy dotyczące planowania przestrzennego obszarów rolnych są niewystarczające. Jednym ze szczególnych narzędzi służących zachowaniu naturalnej funkcji gruntów rolnych jest planowanie przestrzenne podlegające regulacjom zawartym $\mathrm{w}$ dokumentach strategicznych kraju. Zgodnie z nowo opracowaną koncepcją planowania przestrzennego obszarów rolnych proces ten jest dwuetapowy: na poziomie gminy i na poziomie gospodarstwa rolnego. Cele niniejszego opracowania są następujące: 1) analiza skuteczności ustawodawstwa krajowego w zakresie zachowania funkcji przyrodniczej gruntów rolnych; 2) uzasadnienie konieczności uzupełnienia ram prawnych o precyzyjne zasady planowania przestrzennego dla gruntów rolnych; 3) zwrócenie uwagi na nową koncepcję planowania przestrzennego, która wykorzystywać powinna dane katastralne do wykonania analiz przestrzennych GIS i opracowania miejscowych planów zagospodarowania przestrzennego. Aby je zrealizować, wykorzystano dane z krajowych urzędów statystycznych oraz zastosowano metody analizy i syntezy. Wymieniono dane potrzebne do analiz GIS i opracowania miejscowych planów zagospodarowania przestrzennego dla obszarów użytkowanych rolniczo. W artykule stwierdzono, że planowanie przestrzenne jest narzędziem do regulowania użytkowania gruntów rolnych, ustalania warunków dla zachowania i poprawy jakości gruntów, ochrony praw własności gruntów oraz rozwoju udanego i dochodowego agrobiznesu.

\section{Słowa}

kluczowe: grunty rolne, ramy prawne, planowanie przestrzenne, koncepcja, dane GIS 